\title{
Comparing the Post-War Germanies: Breadwinner Ideology and Women's Employment in the Divided Nation, 1948-1970*
}

\section{Christine von Oertzen and Almut Rietzschel}

In 1989 , when Germany became reunified after forty years of separation, no one could overlook the fact that East and West Germany differed greatly with regard to the position of women. The most striking difference of all seemed to lie in the rates of female employment: 91 per cent of all East German women under the age of 60 were counted as being employed, compared to only 55 per cent in West Germany. ${ }^{1}$

These figures give the impression that the male breadwinner system, a solid pillar of the traditional gender hierarchy, had been demolished in the East, whereas in the West it was at best crumbling round the edges. This interpretation also fits neatly into the standard accounts, which stress the differences between the two Germanies. While East German literature celebrated the new gender order by dwelling on women's successful emancipation, West German literature emphasized the view that reinforcing the traditional gendered division of labour was a key element in the reconstruction of society. ${ }^{2}$

Without denying the obvious dissimilarities, we would like to suggest a change of perspective. Shifting the main focus to the question of similarities, we shall trace the history of the male breadwinning experience in East and.West Germany, starting in the turmoil of the post-war years. This approach seems to be particularly promising in relation to the 1950 s and 1960 s, when the common heritage still shaped life in both halves of

- This article is the product of a comparative project on the gender history of post-war Germany. The two authors are both due to finish their theses in 1997. Both studies are on part-time work, Christine von Oertzen's about its history in West Germany and Almut Rietzschel's about its development in East Germany.

I For West Germany (1989) see Friederike Maier, "Zwischen Arbeitsmarkt und Familie; Frauenarbeit in den alten Bundesländem", in Hildegard-Maria Nickel and Gisela Helwig (eds), Frauen in Deutschland, 1945-1992 (Bonn, 1993), pp. 257-279; please note that the East German figure of 91 per cent includes female students and apprentices, see Gunnar Winkler (ed.), Frauenreport '90 (Berlin, 1990), p. 63. Virginia Penrose presents data that are more closely comparable with the West German figures and calculates on this basis that 80 per cent of East German women were employed in 1987: see Penrose, "Vierzig Jahre SED-Frauenpolitik: Ziele, Strategien und Ergebnisse", Frauenforschung: Informationsdienst des Forschungsinstituts Frau und Gesellschaft, 8, 4 (1990), pp. 60-77, esp. p. 66.

${ }^{2}$ For West Germany: Annette Kuhn, "Power and Powerlessness: Women after 1945, or the Continuity of the Ideology of Feminity", German History, 7 (1989), pp. 35-46; for East Germany: Herta Kuhrig and Wulfram Speigner (eds), Zur gesellscrafichen Stellung der Frau in der DDR (Leipzig, 1978).

International Review of Social History 42 (1997), Supplement, pp. 175-196 
Germany. This included the powerful ideology of the male breadwinner family where "the husband was expected to be the main, preferably the sole, breadwinner and his wife was to assume responsibility for running the household, preferably on a full-time basis". ${ }^{3}$ It is true that the East German state deliberately broke with the past by creating a new female role model of women as lifelong, full-time workers. But this does not necessarily mean that the ideology of the male breadwinner was eliminated in East Germany. We assume that it was ostensibly demolished but lived on beneath the surface. Our comparative approach therefore leads to the key issue of this paper: to what extent is the history of the male breadwinning experience really dissimilar or similar in East and West Germany?

Current research on the male breadwinner system has so far concentrated on the nineteenth century. It illustrates how the system was implemented in labour legislation, and how its ideology shaped and gendered class formation in Western Europe and in the US. Its origins and the explanatory factors involved in its rise are still hotly debated. ${ }^{4}$ By concentrating on the twentieth century, when the male breadwinner system was already firmly established, our paper will contribute to the debate by posing other questions: how - and to what extent - did the breadwinner system endure on each side of the German border? And how can we explain its enormous capacity to adapt to changing political, social and economic conditions? ${ }^{5}$

The first two sections of our article analyse how the notion of the male breadwinner continued to shape the perception of women's employment in both halves of Germany. In the late 1940 s, these debates centred on how to provide for war widows (part I). The breadwinner ideology remained influential in the 1950s and 1960s, when the debates on women's work focused on married women (part II). Part III examines the legal institutionalization of the breadwinner ideology, which helped to reproduce a gender system with a strong bias in favour of men. In the case of West Germany, the tax system will be a particular focus of attention, and in the case of East Germany the wage system. During the period of the 1950s and 1960s, the divergent paths adopted by the two German states in the 1940 s became clearly apparent. While the breadwinner ideology was deliberately written into West German legislation, it is more difficult to

3 Colin Creighton, "The Rise of the Male Breadwinner Family: A Reappraisal", Comparative Studies in Society and History, 38 (1996), pp. 311-337.

4 A comprehensive overview of the nineteenth-century debate is given by Creighton, in ibid. For German case studies, see Sabine Schmitt, Der Arbeiterinnenschutz im Deutschen Kaiserreich. Zur Konstruktion der schutzbedürftigen Arbeiterin (Stuttgart, 1995); Kathleen Canning, Languages of Labour and Gender. Female Factory Work in Germany, 1840 1914 (Ithaca, 1996).

5 See Karin Hausen, "Frauenerwebstätigigkeit und erwerbstätige Frauen. Anmerkungen zur historischen Fonchung", in Gunilla Budde (ed.), Frauen arbeiten. Uteibliche Erwerbstätigkeit in Ost- und West-deutschland nach 1945 (Gobttingen, 1997), pp. 19-45. 
detect in East Germany, since the state aimed to eradicate it. The issues we have selected - though differing in the two states - are those which can demonstrate most effectively the mechanisms responsible for the adaptability and persistence of the male breadwinner system.

After World War II, the German authorities of all four occupation zones had to cope with the problem of how to provide for war widows. The widows had lost not only their husbands but also the comfortable pensions instituted by the Nazi authorities. These were abolished by the Allied Control Council in $1945 .^{6}$ Although this did not result in a complete cessation of all public support for widows, the four military governments made it clear that widows under 60 were expected to earn their own living, even if they had children. In the turmoil of the initial post-war years, when everyone was preoccupied with the hardships of daily life, the impact of this policy did not immediately become fully apparent. This changed in the summer of 1948, when the two currency reforms were enacted, first in the West and then in the East. The dual currency reform can be identified as the starting-point of the two diverging paths followed by the authorities in East and West Germany in providing for war widows. Faced with the same problems, the East and West German administrations pursued measures which at first glance appear to be similar, but in fact reflect quite different ideas on how to replace the missing breadwinners.

The dual currency reform had a dramatic impact on the female labour market in both the East and the West. For the first time since 1946, unemployment offices were confronted with growing numbers of women for whom they could not find jobs. While many firms were dismissing workers, the currency reforms also created a new demand for jobs as "money" regained its lost importance and superseded strategies of survival which depended on barter and the black market. Since savings had been devaluated or exhausted, many women who had previously done their best to avoid joining the workforce now registered at the unemployment offices. Others were attracted to paid work because of the renewed availability of goods in the shops. ${ }^{7}$

In East Germany, war widows with dependent children suffered particularly from the increasing competition in the female labour market. Three years after the end of World War II, high-ranking officials left no doubt

\footnotetext{
- A detailed account in a broader context will be given in the forthcoming publication by Elizabeth D. Heineman: Standing Alone: Single Women from the "Third Reich" to the Post-war Germanies. For a general account of women in the post-war years, see her article: "The Hour of the Women: Memories of Germany's "Crisis Years" and West German National Identity", American Historical Review, 101 (1996), pp. 354-395.

${ }^{7}$ For a detailed account see: Katherine Pence, "Labours of Consumption: Gendered Consumers in Post-War East and West German Reconstruction", in Lynn Abrams and Elizabeth Harvey (eds), Gender Relations in German History: Power, Agency and Experience from the 16th to the 20th Century (London, 1996), pp. 211-238.
} 
that the East German state expected the war widows to replace the male breadwinner by seeking full-time employment. By restricting welfare payments as well as pensions to widows under the age of 60 , the East German government tried to "force" the widows into the labour market. ${ }^{8}$ These measures transmitted the clear message that was relentlessly preached to the widows: "We have no obligations toward the Nazi state". 9 In times of high unemployment, even those widows who had adjusted to the new political system and accepted the role of provider found it difficult to fulfil the expectations (and many did not, resolutely claiming that the state was obliged to take care of them because the death of their husbands was no fault of their own).

In 1948/1949, skilled female workers still had some chance of finding work, but many war widows were qualified only for untrained work for which there was no great demand. In addition, many of them had children to care for and could not work eight hours a day in a factory. What made things worse was the decline of the market for domestic production, in which many widows had previously found work. Most of them were dismissed when domestic industry broke down in 1948 due to wage increases, declining sales, scarcity of raw materials and production prohibitions. ${ }^{10}$ In trying to cope with the problem of rising unemployment amongst welfaredependent women with children, the East German labour administration fell back on the traditional idea of creating part-time jobs, which had been developed during the unemployment crisis of the 1930s. This idea of spreading the limited work available over as many women as possible was clearly a solution inspired by necessity rather than by choice. Widows were only to work part-time so long as there were not enough full-time jobs and not enough childcare facilities. The idea failed completely, partly because of the unwillingness of firms to create part-time jobs and partly because women on welfare were not interested in part-time work paying wages that were even lower than welfare support.

Facing truly bleak prospects in their search for full-time work, East German war widows waged a bitter war against married women in the workforce, whom they denounced as "double income earners". In their

- Daniela Weber, "Zwischen Fürsarge und Erwetbsarbeit. Alleinstehende Leipzigerinnem nach dem Zweiten Wellkrieg", in Susanne Schötz (ed.), Frauenalltag in Leipzig. Weibliche Lebenszusammenhänge im 19. und 20. Jahrundert (Weimar, 1997), pp. 295-318. For the restrictions, see "Anordnung zur Durchfuhrung der Verordnung uber Sozialfürsorge und des SMAD-Befehls Nr. 92/1946", which became law on 1 October 1948, published in Zentralverordnungsblatt 1948, pp. 469-473 and "Verordnung uber die Zahlung von Renten an Kriegsinvaliden und Kriegshinterbliebene vom 21.7.1948", ibid. pp. 363-365. It went into operation on 1 November 1948.

9 "Wir haben keine Verpflichtung gegenuber dem Nazistaat", said the high-ranking Saxon Oberregierungsrat Hausdorf during a lecture to local social welfare commissions in July 1949, in Bundesarchiv, Abteilung Potsdam (hereafter BAP), DQ-2 3730.

10 A detailed picture of the decline of domestic industry is given in Sächsisches Hauptstaatsarchiv Dresden (hereafter SächsHStA), LRS, MfAuS, No. 318. 
struggle to compete with other better-trained women, the war widows used the only weapon they had: the provider argument. In December 1949, when the prospect of finding work was particularly gloomy - there were only five vacancies for every hundred unemployed women - the Saxon Ministry of Labour registered a real "storm of protest against 'double income earners" ". Day after day the staff of the labour offices were confronted with angry cries of "Get the 'double income eamers' out of the factories! I need work. I need money to survive. The "double income earners' just squander it at the free shops" (newly-opened state-run shops offering highly-priced unrationed goods, later known as HO-shops). ${ }^{11}$

Male workers sided with the war widows in their desire to banish married women from the labour market. They were ready to grant the widows provider status on condition that they did not compete with men. In 1947, a representative of a factory council suggested in a letter to the local Dresden branch of the Socialist Unity Party (SED) that married women with husbands to support them should be dismissed and their jobs given to welfare-supported war widows. This would mean that his factory could offer 10 to 15 jobs to war widows. The local party unit did not dare to answer this letter, but passed it on to the Saxon government, where it provoked widespread discussion. A high-ranking female official at the Labour Ministry declared that there was "something to be said for it" on condition that married women resigned of their own free will. ${ }^{12}$ In 1948, employment offices in Saxony were advised to adopt this guideline, which seemed to resolve the conflict between social needs and ideological commitment: it acknowledged the war widows' claims without infringing married women's right to work. This policy did seem to make sense in 1947 and 1948, when large numbers of men were retuming from the prisonerof-war camps. The employment offices soon noted that their return often coincided with their wives' decision to give up employment. By 1949, however, it was clear that the Saxon policy was doomed to failure, since those married women who were still in employment showed no inclination to resign. Furthermore, Saxony's cautious admission that the marital status of women might play some role could be read as an implicit agreement that in times of high unemployment war widows should be preferred by the employment offices to married women. For this reason, it provoked a sharp response by the central administration in Berlin, which insisted that jobs should be assigned strictly on the basis of women's qualifications. Women's right to work regardless of their marital status became constitutional law in 1949. It was undoubtedly a noble cause, but it was not the

"The widows cried: "Sorgen Sie dafür, daß die Doppelverdiener aus den Betrieben verschwinden. Ich brauche eine Arbeit. Ich brauche das Geld zum Lebensunterhalt. Die "Doppelverdiener' geben es im freien Kaufhaus aus!", in SächsHStA, LRS, MfAuS, No. 453, p. 31 .

${ }_{12}$ The course of events is documented in SächsHStA, LRS, MfAuS, No. 453, pp. 38, 40 and 41. 
policy followed in practice by the local employment offices, which continued to give clear priority to the war widows. ${ }^{13}$ This was in line not only with the task of reducing welfare expenditure but also with the established practice of employment offices to favour those clients who could claim to be the family breadwinner.

In West Germany, a different solution/policy was pursued. The claim for women's "right to work" could also be heard in the immediate postwar years, but lost its emancipatory meaning and experienced a specific metamorphosis with the beginning of the Cold War. ${ }^{14}$ Women were to have the right to work, but only if they "needed" to do so for economic reasons. Referring to the "naturalness" of the gender system, it was to be women's primary task as well as their primary "right" to care for the family while being supported by a male breadwinner.

Nothing illustrates this policy change between 1948 and 1950 more clearly than the attitudes and policies towards war widows with children. Pressurized by organizations of war-disabled men and POWs, trade unions, the labour ministries ${ }^{15}$ and the communal public welfare organizations, ${ }^{16}$ the labour administrations ${ }^{17}$ began to seek employment for war widows. Nobody denied the difficulty of integrating widows and women

13 See BAP, D Q-2, 2072. This file contains many documents on the campaign against "double income eamers" and the efforts to crush it. The future Minister of Justice, Hilde Benjamin, initiated a review of policy in local unemployment offices when she was told that they refused to give jobs to married women. The Saxon policy was criticized in a letter sent on 17 January 1949 by the employment and welfare department of the central administration to the Saxon Minister of Labour.

14 See Robert G. Moeller, Protecting Motherhood. Women and the Family in the Politics of Post-war West Germany (Berkeley, Los Angeles and Oxford, 1993), esp. p. 319f.

is Up to 1950, there was no central ministry of labour in West Germany. In so far as the allied military governments left anything for them to decide, it was the labour ministries of the "Bundesländer" that govemed all policies concerning the labour market. Especially in the British Occupation Zone, important decisions were taken by the "Manpower Division" of the military government. Within this, the British instituted a "Zentralamt fur Arbeit" (Central Labour Administration), a German authority exercising the executive powers of the manpower division for the whole zone. In the American and French zones, there were no comparable authorities, because labour policies were left much more to the Germans themselves. The labour ministries in all of the "Bundesländer" represented the official authorities. Beside these, the labour administrations on the country (Landesarbeitsämter) and local (Arbeitsämter) level were responsible for finding jobs (Arbeitsvermittlung) and for bearing the costs of unemployment insurance (Arbeitslosenversicherung). The labour administrations were part of the autonomous German labour administration (Arbeitsverwaltung). Destroyed by the Nazis, the central institution of the labour administration (Bundesanstalt fur Arbeitsvermittlung und Arbeitslosenversicherung, BAVAV) was not restored until 1952. Until then, the labour administrations of the Bundesländer (Landesarbeitsämter) represented the highest authorities with regard to job finding and unemployment insurance.

${ }_{16}$ Public welfare (8ffentliche Wohlfahrt) was organized at local level and widely financed by the municipal authorities. The cities and counties had to provide for the public welfare organizations (Wohlfahrtsverbände) which bore the costs of the public welfare system.

$"$ See footnote 15. 
"with family responsibilities" (häuslich gebundene Frauen) into the "normal" and "free" labour market, which were quite similar to the East German case. However, the financial "burden" that these women imposed on the communal welfare system meant that a solution needed to be found. Furthermore, and even more importantly, the aim of "providing" widows with work had an important conceptual background: part-time work would enhance the social integration of war widows and women refugees with children. It would reinforce women's self-confidence and their feeling of being "useful". This interpretation of the meaning of "work" was far from being emancipatory; rather it was clearly shaped by ideas of an adapted male "breadwinner model": going out to work would not only meet an economic need, but would also help to restore the individual power and dignity of the widows and "provide" them with self-achieved economic independence from public support. ${ }^{18}$

In this sense, part-time work was perceived as a less-than-ideal solution, but in a very different way from in East Germany. The war had prevented widows from living their lives in accordance with the social norm of the housewife. Under these conditions, part-time work was the most suitable way for them to function in their new role of provider. West Germans insisted that widows with children could not be expected to cope with a normal full-time job. In some of the larger cities, the labour administrations tried to introduce needlework centres with flexible working hours for mothers who "needed" work (erwerbsbediurftige Mütter). As in East Germany, however, none of these measures lasted long. The introduction of part-time work in industry came nowhere near to realization. Close inspection reveals that attempts to achieve it were blocked at a number of levels. "Radical" women trade unionists, for example, demanded a legal quota to institutionalize part-time work for widows in factories and offices: under regulations for war-disabled men, employers would be fined if they did not make a fixed percentage of part-time jobs available to war widows. However, this demand was tumed down in 1949. In favour of the efforts to institute the quota system for the war-disabled male breadwinners, highranking male trade unionists rejected the proposal.

The most important change in the meaning of employment for widows was promoted by the labour administration and in the legal debate concerning the right to unemployment support. In 1948, in an attempt to integrate widows and women with dependent children into the labour market, the British allies had introduced a new system of state support which was meant to replace the abolished war pensions. ${ }^{19}$ Under the new system, unemployment benefits did not depend on a previous record of

1" Decree of the Hesse Ministry of Labour to the Hesse labour administration, 10 October 1948, Hessisches Hauptstaatsarchiv Wiesbaden (hereafter HStAH), Dep. 940, No. 109.

19 Kurt Draeger, "Die neue Arbeitslosenfürsarge", in Arbeitsblatt für die Britische zone 2 (1948), pp. 41-48. 
employment. This regulation meant that widows who were fit to work ("arbeitsfähige") could apply for unemployment benefits, even if they had never been part of the workforce. As a result, the official employment agencies were responsible for their support, and should therefore be eager to find jobs for them in order to reduce the total costs of the benefits system. But instead of encouraging this effort to provide clients with work meeting their unusual needs, the law actually promoted the opposite. Male workers were still given privileged access to the few jobs available on the grounds of their responsibilities as breadwinners. By contrast, widows, married women and single mothers with "family responsibilities" were labelled as "bogus unemployed" who were "not available" for the labour market because they could not work the whole day. They were therefore excluded from unemployment support and left to the public welfare system. This was worse than unemployment support not only because it often meant lower benefits (which had to be paid back in better times) and no extra health insurance, but also because it was regarded as support for the poor and disabled. Receiving welfare payments meant exclusion from society.

To justify this practice, labour administration officials claimed in 1951 that war widows and refugee women with children did not need work but money. They would be best taken care of by way of satisfactory state pensions. This argument was consistent with another topic that was dominating the political agenda and attracting great interest at the time: from 1945 on, the West German authorities had aimed to change allied policies on widows and war-disabled men, which were perceived as degrading. ${ }^{20}$ In 1950, a new law restored the abolished state support for the "victims of the war". This milestone in West German reconstruction sanctioned a clearly gendered concept of state provision. Whereas it explicitly provided for a combination of "work" and "support" for disabled men, it reinforced the ideal of widows as housewives and mothers, which included "work" only in a very subordinate way. What widows with children "needed" in the first instance was full financial support in the form of state pensions. Defined in this way, they were excluded from the "right to work". The legal quota system provided "work" primarily for disabled male victims of the war - it was only to be given to widows if no war-disabled man was available. ${ }^{21}$

When the "double income" campaign emerged in West Germany at the beginning of the 1950s, it had a very different connotation from the one in East Germany. The Western campaign built upon a clearly gendered

${ }^{20}$ Up to 1949, however, West Germans had no legal sovereignty and thus had to cope with the problems of disabled breadwinners, who could hardly be integrated into the workforce, as well as with widows for whom it was impossible to "provide".

${ }_{21}$ Bundesversorgungsgesetz of 12 December 1950, Bundesgesetzblatt I 1950, pp. $791 \mathrm{f}$. 
hierarchy: it insisted that no married women should be employed so long as any male worker was in need of a job to fulfil his duty as a breadwinner. The "need" for jobs for widows and women without male support was not completely ignored in this chorus of discrimination against the employment of married women, but it had no lobby comparable to that in East Germany. Improving the situation of West German widows meant calling for higher pensions. Despite the fact that most widows were unable even to survive on this support and therefore had to seek full-time or part-time employment, they were still regarded as being "provided for" in a reconstructed breadwinner system.

As the years passed, all East German war widows were integrated into the workforce. As a result, the proportion of women in employment almost equalled that of men. In 1950, 40 per cent of the workforce was female, and ten years later 45 per cent. Even more impressively, the percentage of women in the 15 to 60 year age group who were in employment rose from 44 per cent in 1950 to 62 per cent in 1960 . Judging by these figures, the new model of lifelong employment for women seemed to have taken secure root. But this picture does not reveal the whole truth. The rising numbers of women in employment were partly due to a significant shift in the age structure of East Germany's population. Because the number of women of employable age was declining, the percentage of women in employment rose rapidly without any significant rise in the actual numbers in work. To put it the other way round: a considerable proportion of married women remained outside the workforce. ${ }^{22}$ To some extent this was to be expected. People needed time to adapt to the new system. First, older couples who had grown up with the breadwinner/housewife ideology and organized their lives accordingly were unlikely to change their lifestyle just because the East German government tried to institute a new ideology. Though the state did not encourage married women to stay at home, it did not attempt to force them into the labour market either. So iong as husband and wife agreed between themselves on the traditional division of labour, the state did not interfere. Second, although young women might adapt more easily to the new role model, many left the workforce after giving birth to children if the husband's wages were enough to support the family

22 Since East German statistics did not count married women as a separate category, this conclusion has to be reached by deduction. In $1955,3,395,600$ women were in employment, equivalent to 55 per cent of all women of employable age. Although five years later only 60,800 more women had joined the workforce, the proportion of women in employment soared to 62 per cent. All figures presented in this paragraph are taken from Penrose, "Vierzig Jahre SED-Frauenpolitik", p. 66. 
because they still believed that a small child needed its mother and should not be placed in institutional care. ${ }^{23}$

On the other hand, some mothers who would have preferred to return to work after their maternity leave were forced to stay at home because they could not get a place in a crèche (for the under-threes) or later in a kindergarten (for the three to six year olds). This problem cannot be explained away simply as a difficulty of the transitional period. It is true that a dense network of childcare facilities could not be constructed overnight, but the slowness of the process was due partly to the fact that the male breadwinner system remained deeply ingrained in East German policies towards women, despite efforts to abolish it. For example, married women who tried to obtain a childcare place were asked whether they owned a TV or a fridge: if so, they did not need to work and therefore did not need a place in a crèche. ${ }^{24}$ Even high-ranking male politicians did not really want mothers to join the workforce. They gave due public support to the official goal of all women entering full-time employment in order to achieve true emancipation, but some of them were only paying lip-service to the official communist doctrine. This became evident in 1961, when the chronic labour shortage led to renewed efforts to attract housewives into the labour force. Former Minister of Labour Fritz Macher was not the only one who admitted privately that mothers of small children would be better off staying at home because "these workers cost us more than they produce". ${ }^{25}$ This calculation could only be based on the assumption that it was women's natural duty to take care of their children. Only within the logic of the breadwinner ideology did it make sense to weigh the expenditures for building and maintaining childcare facilities against women's productivity.

Nevertheless, high-ranking male officials did make this calculation and therefore favoured part-time, rather than full-time, work for mothers because they assumed it was "cheaper". In late 1960, when Clara Zetkin's son, the professor of medicine Maxim Zetkin, proposed incorporating a right for mothers to work part-time into the new statute of industrial law, his chances of success were not very high. Many SED and trade union officials feared (correctly) that women currently working full-time would be encouraged to reduce their working hours. Zetkin's proposal was, however, strongly supported by the state council, the collective body headed

2] In 1960, the question of "who is the better mother?", those staying at home or those going out to work, was fiercely debated in the SED newspaper Neues Deutschland: see Gesine Obertreis, Familienpolitik in der DDR 1945-1980 (Opladen, 1986), pp. 157f.

24 See the lecture on problems of socialist education given at the meeting of the women's committee of the FDGB executive on 31 May 1961 in Stiftung Archiv der Parteien und Massenorganisationen der DDR im Bundesarchiv (hereafter BA-SAPMO), DY 34/4238.

${ }_{25}$ The off-hand remark "daB diese Arbeitskräfte uns mehr kosten als sie bringen" was made to a female union colleague during a conference of the FDGB executive: see memo written by Fridl Lewin on 7 April 1961, in BA-SAPMO, DY 34/2146. 
by Walter Ulbricht. Its members were fascinated by the concept of parttime work because it made women's work outside the home more "profitable". Scientific research was enthusiastically cited to "prove" that mothers who worked part-time organized the day care of their children privately and did not need expensive state-run childcare facilities to combine the roles of mother and paid employee. This was not the only advantage of part-time work in the eyes of party and state officials. They also calculated that staff not required for childminding in state facilities could instead be diverted into "productive" branches of the economy. ${ }^{26}$ The intervention of the state council doubtless smoothed the way for the eventual grant of the right to work part-time to women whose "family duties" temporarily prevented them from working full-time. ${ }^{27}$

The discussions on the "profitability" of women's work indicate that the breadwinner ideology was still shaping the debates on married women's employment. The strength of its influence becomes even more obvious when the framework of policy towards women is examined closely. Policy towards women, as defined by the SED, still assumed that women remained responsible for running the household and caring for the children, even when they had joined the workforce. This unquestioned assumption was what lay behind the concept of relieving mothers in fulltime employment of as many household tasks as possible. Even female politicians like former Social Democrat Käthe Kern, who fought hard to establish equality between the sexes in the workplace, failed to recognize that the ambitious plan to help women combine the roles of mother and worker helped to confirm the traditional gender division within the family. The manifold measures they initiated to ease women's "double burden" (e.g. building childcare facilities, laundries and factory canteens) certainly satisfied women's needs, but at the same time they reinforced the notion that bringing up children and doing the housework were women's work. How deeply this notion was embedded in East German policies towards women is indicated by the language employed by party and trade union officials - of both sexes - to define the goals of these policies. They constantly spoke of women's duties as mothers, wives arid housewives, as if this were the most natural thing in the world. Only on very rare occasions was this language ever closely scrutinized. The following anonymous author, who attempted to evaluate the state of policies towards women in the mid-1960s, was one of the few who grasped the significance of language in this respect. The often-cited term "women's duties as wives and mothers", this author pointed out, "is not used in such a way that it

${ }^{26}$ Letter of 6 January 1961 from the state council to the executive of the FDGB, in BASAPMO, DY $34 / 217 / 281 / 6389$.

${ }^{27}$ Section 3 (4) of the Gesetzbuch der Arbeit stated: "Die Betriebsleiter sollen die Möglichkeiten schaffen, daß auch die Frauen, die durch familiäre Pflichten vorlbergehend verhindert sind, ganztłgig zu arbeiten, durch Teilbeschäftigung ihr Recht auf Arbeit wahmehmen können", in Gesetzblatt 1961, Part I, p. 29. 
can be assumed that women regard this work as their duty, but that it is their duty". 28

The constant reference to the special duties of women supported the traditional division of labour within the family. This system of ascribing all unpaid housework to women had a clear impact on the way in which the East German population thought about women's work, as is shown by two opinion polls on the role of women in the family and in society which were conducted in 1968 and 1970. Admittedly, both surveys document the radical change in attitudes towards women's employment. In contrast to West German attitudes, an overwhelming majority in the East now approved of the employment of married women outside the home. But only 25 per cent of those surveyed were prepared to agree with the official role model of women's lifelong full-time employment, whereas more than 50 per cent accepted the idea of part-time work after marriage. Worse still, male industrial workers - whom the Marxist-Leninist ideology regarded as the avant-garde - were particularly tenacious in their preference for the housewife model. Around 30 per cent of the male factory workers surveyed thought that married women should not work at all, or should at any rate give up work once the necessary household items had been bought. ${ }^{29}$

In West Germany, the debate on the employment of women shifted its focus to married women once the economic situation improved during the 1950s. It was almost unanimously agreed that the best help for a married woman - unless she was highly qualified - was a good job for her husband. Even female union officials fighting for equal rights and pay for women in the labour market did so on this premise: married women were to be protected as workers only so long as the breadwinner system lacked efficiency and failed to support a family on a single income.

Despite these notions, the female workforce rose steadily once the peak of unemployment had been overcome in 1952. Moreover, the percentage of married women workers shot up and married women became increasingly visible in the labour market. At the end of 1954, when the government and industrial federations were predicting full employment and a future economic need for even more female married

28 "Der Begriff Pflicht [werde] nicht so verwendet, daß man annehmen könne, die Frauen wirden diese Arbeiten als ihre Pflicht betrachten, sondern als seien es ihre Pflichten": (undated) analysis of the state of scientific work on "The woman in the socialist society", in BA-SAPMO, DY $34 / 4293$.

29 Both surveys are documented in BA-SAPMO, DY 30/IV 2/2.042/2. Included in the 30 per cent of male factory workers are those who preferred not to answer this question. Although the opinion polls were conducted by an institute supervised and controlled by the SED (Institut fur Meinungsforschung beim ZK der SED), they can be regarded as providing a true picture. The participants had to fill out a written questionnaire which could not be traced back to the individual participant. 
workers, the question of part-time work once again came up for debate. Once more, discussions centred around the meaning of "work" for women. The debates on part-time work during the 1950s were devoid of any idea of sexual equality with regard to the duties of paid work and family work. In fact, they centred explicitly on the "double burden" borne by married women workers and women's associations - and even the women's branch of the trade unions (DGB) - only accepted concepts of married women's work that relieved women of the burden of full-time gainful employment in order to preserve their energies for their domestic duties. ${ }^{30}$

So long as married women's work could be justified on the basis of "economic need", it did not threaten traditional beliefs concerning gender relations. Yet the ever-growing percentage of married women in the workforce demanded new ways of coping with the "biggest social revolution of our times", as a national newspaper put it in 1956." Official figures seemed to confirm this perception: between 1950 and 1961 the percentage of married women in the female workforce rose from 19 to 35 , and by 1970 as many as 50 per cent of all women workers were married. ${ }^{32}$ It is obvious that this trend did not decline with the dawn of economic prosperity in the late 1950 s, although those years marked the peak of the breadwinner ideology and practice. For the first time, increased male wages made it possible for families actually to live solely on the income of the male breadwinner. Ironically, however, employers and the government were at this very time encouraging married "housewives" to enter employment in order to alleviate the constant labour shortage.

Under these circumstances, attitudes towards married women's employment began to change. Their participation in the labour force could no longer be explained away or excused as a failure of the male breadwinner system. In the early 1960 s, the economic and social shift from deprivation to prosperity undermined these justifications. ${ }^{33}$ The argument that the

${ }^{30}$ For the women's associations see: Halbtagsarbeit - Teilzeitarbeit - fur Frauen. Report of a nation-wide conference hosted by the "Arbeitsgemeinschaft "der Wählerinnen" in Munich, 27 to 29 October 1955, Manuscript, Deutsches Zentralarchiv fur soziale Fragen, ZI 13349; Olga Amann, "Halbtagsarbeit für Frauen", in Ruth Bergholtz (ed.), Die Wirtschaft braucht die Frau (Darmstadt, 1966), pp. 222-237; for the trade unions: "Da haben wir uns alle schrecklich geimt [...]", German trade unions (DGB) (ed.), Die Geschichte der gewerkschafilichen Frauenarbeit im Deutschen Gewerkschaftsbund von 1945-1960 (Pfaffenweiler, 1993).

${ }^{31}$ Westdeutsche Allgemeine Zeitung, 11 January 1956.

32 For these figures, see Angelika Willms, "Grundzilge der Entwicklung der Frauenarbeit von 1880-1980", in W. Muller, H. Willms and J. Hanell, Struktunwandel der Frauenarbeit 1880-1980 (Frankfurt/M., 1983), p. 35.

${ }^{33}$ Claudia Bom and Helga Krueger (eds), Enwerbsverläufe von Ehepartnern und die Modernisierung weiblicher Lebensläufe (Weinheim, 1993); Michael Wildt, Am Beginn der Konsumgesellschafi. Mangelerfahrung, Lebenshaltung. Wohlstandhoffnung in Westdeutschland in den füfziger Jahren (Hamburg, 1994). 
employment of married women was a reflection of economic "need" became an insult to every male breadwinner's capacity to provide for his family and threatened his social prestige. It was only tolerable for "housewives" to go out to work if they did not do it for economic reasons, but rather to satisfy a personal "need" or to achieve a "better life" in a modern consumer society. Detached from mere economic need, "work" for married women became more openly a matter of their own decision and desire. This option created a new image of the married woman worker. Alongside the exploited victim of hostile economic conditions, there now appeared on the scene the self-confident and active wife who sought employment in order to earn some extra income and for the sake of a pleasant change from the everyday routine of house and family work.

This image did in fact match the reality of the new clientele being addressed by the intense efforts to recruit women into the labour market. ${ }^{34}$ The high level of breadwinners' incomes now gave "housewives" a stronger position from which to claim improved working conditions, such as special arrangements for working hours or transport to the workplace. The increasing percentage of married women in employment was partly due to the growth in part-time work. Between 1958 and 1970, the proportion of part-time workers in the female workforce rose from about 4 to over 19 per cent. Most women working part-time were married and had children; in 1970, every second married mother in the workforce had a part-time job. ${ }^{35}$

"The working housewife has become a hit", the well-known journalist Rosemarie Winter noted in October 1960 in a radio magazine programme on part-time employment. ${ }^{36}$ She hastened to add that she would not deny that many families still had an urgent need for women's additional income. Nevertheless, compared to the 1950s, something in the meaning of work had definitely changed: "Whether or not married women are working for economic reasons, people think it is good for them: a vivid experience, a change from domestic routine, something to talk about, and even a matter of prestige." ${ }^{37}$ Even men, she continued, would talk about their working

${ }^{34}$ See, for example, the page one banner headline of a famous daily yellow press newspaper, "Damit lockt die Industrie die Hausfrauen": Bild-Zeinung, 16 September 1961.

${ }^{35}$ In 1970, the proportion of married women workers in part-time jobs who had no children was 41 per cent. For all figures (except those referring to 1958) see: "Frauen mit Teilzeitarbeit. Ergebnisse des Mikrozensus", Wirtschaft und Statistik (1971), pp. 416-418; "Die Erwerbstätigkeit der Multer und die Betreuung der Kinder. Ergebnis der MikrozensusBefragung 1969", ibid., pp. 68-88. For 1958 see: Gewerkschafiliche Beiträge zur Frauenarbeit, Heft 3: Ergebnisse einer Befragung nber die Belastung der enverbstatigen Frauen durch Beruf, Haushalt und Familie (Dusseldorf, 1961), p. 25.

36 "Sie sucht Zuverdienst". Script for a radio magazine programme broadcast on 10 October 1960 by Rosemarie Winter, HStAH, Abt. 2050, No. 36.

37 "[...] ganz allgemein und uberall [sieht man] in der Berufsarbeit der Hausfrau, ob sie nun eine Existenzgrundlage oder Zusatzverdienst bildet, eine Erfahnungsbereicherung, eine 
wives with pride - so long as they benefited from the higher family income without having to sacrifice valued privileges. The debates on the tax system discussed below show that one key "privilege" which was to be upheld was their status as breadwinners, which was linked to substantial benefits, both inside and outside the home.

By the mid-1960s, part-time work was becoming an established part of the new and widely accepted idea of married women's lives. It was seen as representing a specific compromise between women's personal or economic needs and their distinct social role in both the family and the workforce, without weakening the male breadwinner ideology. All political parties and even the churches gave part-time work a key position in their ideas for a "family policy" taking account of the changing social and economic conditions in West Germany. Social-democratic women became the first to promote part-time work in this way. They included emancipatory intentions and deduced the "right" to work (part-time) from a new and "Western" female lifestyle; with more or less hesitation, the conservative " $c$ "-parties ${ }^{38}$ and both the Protestant and the Catholic church subsequently approved part-time work, because it allayed deep-rooted fears that integrating married women into the labour market would destabilize gender hierarchies both within the family and in society as a whole.

\section{III}

Images and meanings of "work" for men and women which are written into norms and regulations shape gender hierarchies and vice versa. The analysis of the treatment of married women's income in the West German tax system provides a prime example of these complex interdependencies. Starting in 1950, the debates on "spouse taxation" (Ehegattenbesteuerung) mirror the changing view of women's work in relation to the breadwinner's income and status. At the beginning of the 1950s, married women in gainful employment paid their own taxes. These regulations were still formally based on legislation introduced by the Nazis. Immediately after coming to power in 1933, the Nazi authorities had repealed the Weimar taxation rules so as to make married women's income once again subject in general to a "household taxation", as it had been until 1922. This measure was clearly meant to discourage and discriminate against the employment of married women. But in 1942, in order to recruit women into the war industry, the tax system was changed again: as under the Weimar laws, married women's income was now taxed separately so long as it resulted from gainful employment.

Abwechlsung und Ergänzung des eintönigen Einerlei, einen Gesprächsstoff, der Anlaß zum Mitreden gibt, ja sogar einen Geltungsfaktor [... .", ibid., p. 1.

${ }^{38}$ The Christian Democratic Union (CDU) and the Bavarian Christian Social Union (CSU). 
The first attack by the Ministry of Finance on married women's taxation coincided with the height of the "double income campaign" in 1950. As mentioned above, this campaign marked a significant change in attitudes towards widows and towards married women's "right" to work. In this context, however, it is obvious that the West German authorities could not easily dispute married women's place in the workforce. Given the determined resistance by the social-democratic opposition in parliament and the vigorous protests by women all over the country, the plan was doomed to failure. However, the conservative government parties succeeded in gaining cross-party agreement that a serious review of spouse taxation was required. The main conflict in the West German parliamentary debates centred on the question of whether a wife's earnings should again be subjected to a general household taxation or be taxed as her own separate income. The former system would clearly produce a higher level of taxation on the whole "family" income than the latter; on the other hand, it recognized the dominant status of the male breadwinner as "head" of the household and was meant to discourage married women from working and restore the "natural order of the sexes"."39

The debate continued until 1958. Finally the Supreme Court rejected the idea of household taxation. Based on its suggestions, the new tax law introduced separate taxation and equal rights for men and women: if both husband and wife were employed, their earnings were to be taxed in the same way and be given the same fiscal status. Consequently, husbands would lose their tax status as sole breadwinners in their families and would have to share with their working wives all the benefits of that status, including general tax rebates, flat rates on professional outlay, and deductions for children. ${ }^{40}$

When the law came into force in September 1958, married male workers reacted with pure indignation. Many of them would not allow their wives to continue working. This was especially awkward for employers in "female" branches of industry with a heavy demand for seasonal and part-time work. Innumerable women resigned from one day to the next, complaining that their jobs were no longer "worthwhile". ${ }^{41}$ The economic situation in the late 1950s favoured this attitude: it was easier now for families to do without the extra income from women's "insignificant" work (geringfïgige, d.h. versicherungsfreie Beschäftigung). As a result, however, employers faced severe labour shortages. Politicians and the administration had to react instantly.

39 See Ministry of Finance memorandum on the taxation of spouses, 18 November 1955. Bundesarchiv Koblenz (hereafter BAK), B 126/6296, o.P.

40 Tax law (Steueränderungsgesetz), 18 July 1957, BGB1. 1, p. 473.

${ }^{41}$ Numerous petitions give vivid impressions of the situation in different branches of manufacturing and other industry, as well as in the newspaper world and the dairy industry. An impressive summary can be found in Petition of the German Federation of Industry and Commerce, Frankfurt, to the Ministry of Finance, 28 October 1958, BAK, B 126/19006. 
Petitions to the Ministry of Finance urging the government to change the law reveal why it provoked so much resistance. ${ }^{42}$ In the first place, it turned out that legislation had simply "overlooked" the high percentage (25 per cent) of married women with an "insignificant" (geringfiggiges, steuerfreies) income. For all these couples, "equal taxation" meant losing half of all tax deductions, because the wife's income was tax-free anyway. The wife could not use the tax deductions, but nor could they be transferred to her husband's income.

The Ministry of Finance reacted quickly to this complaint. In order to rescue the harvest for the canning industry ("Konservenkampagne") in the autumn of 1958, the law was changed within a month to allow the wife's tax deductions to be transferred to the husband's tax return where the wife's income was below the tax threshold. The result of this amendment was to reinstate the tax privileges enjoyed by the breadwinner prior to the tax reform. It went even further: the new tax regime could actually save the family money if the wife's income was lower than 1,200 DM a year.

However, the new regulations did not stop the vigorous complaints. They made taxation subject to an extremely complicated procedure. If the wife went out to work, she still needed a detailed pay slip (Lohnstetterkarte), even if her modest earnings were not subject to tax. Furthermore, the husband had to ask his employer to issue him with a detailed pay slip, showing tax deducted, and get the taxation bracket (Lohnsteurerklasse) changed from "III" to "IV" at the local tax office (Finanzamt). Not only villages, but even towns like Wolfsburg did not have their own official office, so that it could take a whole day to get the slips changed. If a wife participated in several types of seasonal work spread over the year, the whole performance had to be repeated at the beginning and end of each period of work. The sources show that many people - husbands - just did not see the point of this "waste" of time and energy.

Even more important in provoking lasting resistance was yet another change that had accompanied the original tax reform: the technique of taxation made public what spouses could hitherto keep secret. Women disapproved of the system and stayed at home in order to maintain the male breadwinners' (and their own) respectability. The reason was that to obtain the tax form, they now had to apply for it from the local authority. In small municipalities they would be personally known to officials and the official application would amount to swearing an oath of disclosure: it would look as if they "needed" the work and the money.

Men complained that they feared loss of standing in the workplace if it became known that their wives worked. This seemed to be particularly embarrassing for high-ranking and skilled workers, as well as for

42 All petitions quoted can be found in BAK, B 126/19006. 
employees in white-collar branches. Although this argument attracted much sympathy, further investigation reveals much greater ambivalence. Married male workers were not afraid of being looked at askance by their colleagues because their wives earned a little money on the side. As could be shown above, wives' "working on the side" (Mitarbeit/Zuverdienst) was widely accepted, provided that these "extra earnings" did not affect the men's status as breadwinners. However, it was completely unacceptable - and therefore best concealed - when husbands lost the privileges of their former tax bracket (III). As the change in tax bracket only had a negative impact on the "family income" as a whole if the wife's earnings were almost as high as the husband's, other than merely financial reasons must have provoked the men's resistance. The change in taxation status seemed not only to threaten men's privileges, but also their identity as sole breadwinners.

In the face of the vigorous complaints, the Ministry of Finance took action to undermine the hard-won principle of equal taxation. Since an immediate response seemed to be required, the Ministry officials decided to introduce a separate new tax form for women (Lolhnsteuerkarte F) which would eliminate the related tax status of the spouses. By defining the family income as "an entity", the new form treated the women's "extra" earnings as a "second income" of the breadwinner. Consequently, if their earnings exceeded the tax threshold, they were charged tax at a high rate and lost all rebates and child deductions. Thus, married women who wanted to work were no longer dependent on their husbands' consent. On the other hand, men no longer needed to reject their wives' wishes, because their taxation status as breadwinners was not challenged. ${ }^{43}$

This solution swiftly took the heat out of the situation. It eased the situation in the labour market, but did much more than that: the new tax form for married women with low earnings provided a highly effective instrument to deal with the general trend of increasing numbers of married women joining the workforce. Hastily introduced for those below the tax threshold in 1961, the gendered taxation of spouses became an integral component of the West German tax system in 1965. The new tax law offered two tax options to all wage earning married couples. If the male breadwinner was unwilling to share his privileged status with his wife, her income would be taxed at a high rate without any deductions. In West Germany, it was only under these terms that the idea of the married woman worker could gain acceptance.

In East Germany, the traditional wage system based on the principle that men were entitled to higher wages than women was strongly defended by male workers. How strongly becomes evident when analysing the history of the famous Order No. 253, by which the Soviet Military Govern-

${ }^{43}$ Advice to local councils conceming the new tax form (Lohnsteuerkarte F), 12 December 1960, BAK, B 126/19006, pp. 161-166. 
ment (SMAD) is usually credited with implementing the principle of equal pay for equal work in August $1946 .{ }^{44}$ This was true only in a very strict sense, since the law did not cover typically female occupations like those in the textile industry. An explanatory letter from the SMAD made it very clear that Order No. 253, which required "equal pay for equal work regardless of age and sex", referred only to women performing men's work. ${ }^{45}$ Any work which did not require exactly the same degree of physical strength was not rated as equal and could therefore be less well paid. There is no doubt that leading female politicians did their best to combat the systematic undervaluation of female work. Their efforts were supported by the East German trade union, the Free German Federation of Unions (FDGB), whose leaders at least recognized the need to increase women's wages. The union made the best of Order No. 253 by drawing the conclusion that it meant that skilled female workers should not be paid less than their male unskilled colleagues. ${ }^{46}$ Even though this plan did not openly challenge the traditional wage hierarchy, since the male pay-lead was only to be reduced, not eliminated, it still met with strong resistance.

Though most employers and trustees were unwilling to increase women's wages, they were not the main obstacle, as leading female SED and FDGB officials discovered on their study tours. They observed that it was factory councils (Betriebsräte) which most fiercely opposed the idea of paying women at least the minimum male wage. ${ }^{47}$ In our opinion, it was not the wage increase that the workers' representatives resisted most bitterly, but rather the whole idea of comparing men's and women's wages. Comparing skilled female work with unskilled male labour was just one step away from comparing skilled work by both sexes, and that would have put an end to the systematic undervaluation of female work. Because the comparison threatened to undermine a gender order that guaranteed high breadwinner wages for men, factory councils did their best to prevent the proposed wage increase from being implemented. Close

${ }^{4}$ Order No. 253 was published together with explanatory notes in Julirbuch für Arbeit und Sozialfürsorge, Bd. 1 (Berlin, 1947), pp. 317-319. For a celebratory account written by East German historians, see Marlies Eilenstein and Emst Schotte, "Die Durchsetzung des Prinzips 'gleicher Lohn fur gleiche Arbeit' fur Frauen in der damaligen Sowjetischen Besatzungzone", Jahrbuch fitr Wirtschafisgeschichte, 3 (1975), pp. 43-52; the critical analysis given in the present paper is based on Christine von Oertzen and Almut Rietzschel, "Neuer Wein in alten Schläuchen: Geschlechterpolitik und Frauenerwerbsarbeit im besetzten Deutschland zwischen Kriegsende und Währungsreform", Ariadne: Almanach des Archivs der deutschen Frauenbewegung, 27 (1975), pp. 28-35.

4s The SMAD's interpretation was published as a commentary on the Order in the Jahrbuch für Arbeit und Sozialfürsorge, see footnote 44.

${ }_{46}$ Internal letter from Friedel Malter to the trade union's executive on 28 October 1946, enclosing an account written by a committee set up by the women's section of the ZK of the SED after a study tour of Saxony, in BA-SAPMO DY 34/A 281.

${ }^{47}$ Account concerning the implementation of Order No. 253, written after a study tour of Thuringia in November 1946, in BA-SAPMO DY 34/A 281. 
scrutiny of their arguments reveals how deeply the systematic wage discrimination against women was ingrained in society. Women earned less than men not just because they did not have the same qualifications, but in fact because their work was stripped of any qualifications at all. A workers' representative in a confectionery factory vehemently refused to compare the work of a skilled female worker who received 0.56 Reichsmark per hour with that of a male unskilled labourer loading and unloading goods. His work, he argued, required more physical strength and ought, therefore, to be paid better. When this traditional explanation was challenged by pointing out that female workers also performed packing work, this workers' representative argued that women's packing work differed greatly "because it does not require any skill at all". ${ }^{48}$ This strategy of classifying female work as unskilled and requiring no special knowledge or training was widespread. Male workers preferred to believe that aptitude and dexterity were simply innate qualities of the female sex. Because they were assumed to be part of "women's nature" and refused the label of "acquired skill", such abilities did not need to be reflected in pay scales.

East German male workers and their representatives could not prevent the abolition of separate wage and salary classifications for men and women (which was upheld by the courts in West Germany ${ }^{49}$ ). Though they lost this battle, they did not face complete failure. The introduction of six (1948/1949) and later eight (1953) wage scales classifying workers regardless of sex but in accordance with their qualifications did not mean the end of privileged breadwinner wages. Beneath the veneer of equality, the idea lived on that a "woman's wage" was a second income and not meant to support a family. ${ }^{30}$ In 1988 , after four decades of serious efforts to raise women's qualifications, most female production workers (Produktionsarbeiterinnen) still found themselves on the lower wage scales, whereas their male colleagues dominated the higher ones. Fifty-six per cent of female production workers received wages on scales 4 and 5 , compared with 21 per cent of male production workers. The latter fared better in the prestigious wage scales 7 and 8 , occupied by 43 per cent of male production workers but only 13 per cent of their female colleagues. ${ }^{51}$ This pay gap may have been due in part to real differences in qualifications, but was certainly also "achieved" by putting men on to higher wage

48 In German "weil sie keine besonderen Fahigkeiten erfordern": for the complete reference see footnote 45.

49 Petra Drohsel, Die Lohndiskriminierung der Frauen. Eine Studie über Lohn und Lohndiskriminierung von erwerbstätigen Frauen in der Bundesrepublik Deutschland, 1945-1984 (Marburg, 1986).

so See Rosemarie Eichfeld, "Frauenerwerbstátigkeit, Qualifikation und Entlohnung in funf Betrieben des Kreises Freiberg/Sachsen in den Jahren 1945 bis 1980", in Karin Hausen and Gertraude Krell (eds), Frauenerwerbsarbeit: Forschungen zu Geschichte und Gegenwart (Munich, 1993), pp. 167-185, esp. pp. 176-179 and 181-185.

si Winkler, Frauenreport '90, p. 91. 
scales than they could claim on the basis of their qualifications. ${ }^{32}$ This procedure allowed breadwinner wages to be introduced through the back door. The tacit assertion of men's privileged position overcame all efforts to close the pay gap. The SED struggled in vain to do so by abolishing the two lowest wage scales for unskilled work. When this was achieved in 1980, it meant pay increases for the women concerned but not the end of the systematic undervaluation of female work.

\section{CONCLUSIONS}

Summing up the evidence and trying to evaluate the similarities and differences in the male breadwinner experience in East and West Germany, we would like to suggest three conclusions. First, although the East German experience differed fundamentally from that in the West, the evidence shows that the standard account of East German women's history needs to be revised to take account of the fact that the breadwinning ideology was much more influential than previously thought. Second, the gap between the two states, which had been narrow in the 1940s, widened in the 1950s and 1960s. The greatest similarities are to be found in the immediate post-war years, when part-time work was seen as a possible solution to the problem of providing for the war widows. Even at this stage, however, there were considerable differences. In West Germany the problem was eventually to be solved by pension schemes based on the idea that mothers should not be in employment but should stay at home. In East Germany, by contrast, war widows were expected to work full-time. The differences became much stronger in the 1950s when the two halves of Germany tried to implement/encourage diametrically opposed female role models. Taken at face value, the ideologies could not have been more dissimilar. Examined more closely, however, the differences appear smaller. In East Germany, the persistent reservations about the employment of mothers reveal that the breadwinner ideology survived beneath the official norm of the lifelong, full-time working mother. That the dissimilarities should not be overstated is also supported by the West German experience of the 1960s. Here, the breadwinner ideology remained strong indeed, although economic prosperity brought growing opportunities for married women to work and prompted the change from the "housewife" norm to the new role model of the "working housewife". Third, the East German experience suggests a new model of the male breadwinning system. It differs fundamentally from the established one in that women regardless of their marital status - were given the same "right to work" as men. However, the new model still deserves to be labelled as a breadwinner system because it suffered from one severe flaw: the policy of equality between the sexes did not include any reform of the deeply gen-

32 Eichfeld, "Frauenerwerbstätigkeit", p. 177. 
dered system of labour division within the family. From the beginning, women were ascribed "special" duties as wives and mothers. How deeply this line of thought remained ingrained in East German policies is revealed by the debate on mothers' "profitability" as workers.

Finally, we would like to comment on another key aspect of the male breadwinner system: its enormous capacity to adapt to very different political frameworks seems to be the secret of its persistence. Tracing its development at the legal level reveals the mechanisms of its propagation. The process of writing the male breadwinner system into law was the result of tangible processes of negotiation. These are not only detectable at the institutional level: our analysis of the East German wage system and the West German tax system illustrates that individual men and women took an active part in the process of propagation.

As the West German case shows, the battles to defend and claim breadwinner's privileges were fought in a very private sphere: they were decided within families, between the spouses. When husbands complained and insisted on their tax privileges as breadwinners, wives gave in. Women had two main reasons consciously to surrender the principle of equal taxation: first, they recognized a shared interest in upholding the respectability of the family. Second, they gave up the power struggle for the sake of domestic harmony. In the short run, this strategy brought married women increased personal freedom (Handlungsspielräume) and greater financial independence, even if they did not participate in tax benefits. Furthermore, they were ready to accept tax discrimination because they themselves saw their earnings as "extra" income. Thus, by actually challenging the practice of breadwinning, they unconsciously helped to reinforce its ideological framework, even though - in the long run - they did not profit by it. 